\title{
Diversity and honey properties of stingless bees from meliponiculture in East and North Kalimantan, Indonesia
}

\author{
SYAFRIZAL ${ }^{1}$, RICO RAMADHAN ${ }^{2,8}$, IRAWAN WIJAYA KUSUMA ${ }^{3,7}$, SAAT EGRA $^{4}$, \\ KUNIYOSHI SHIMIZU ${ }^{5,9}$, MAMORU KANZAKI ${ }^{6}$, ENOS TANGKE ARUNG ${ }^{3,7, \bullet}$ \\ ${ }^{1}$ Department of Biology, Faculty of Mathematics and Natural Sciences, Universitas Mulawarman. Jl. Barong Tongkok No. 4, Gunung Kelua, Samarinda \\ 75123, East Kalimantan, Indonesia \\ ${ }^{2}$ Department of Chemistry, Faculty of Science and Technology, Universitas Airlangga. J1. Mulyorejo, Surabaya 60115, East Java, Indonesia \\ ${ }^{3}$ Faculty of Forestry, Universitas Mulawarman. Jl. Penajam, Kampus Gunung Kelua, Samarinda 75123, East Kalimantan, Indonesia \\ Tel.: +62-541-749068, Fax.: +62-541-735379, "email: tangkearung@yahoo.com \\ ${ }^{4}$ Faculty of Agriculture, Universitas Borneo Tarakan. Jl. Gunung Amal, Pantai Amal, Tarakan 77116, North Kalimantan, Indonesia \\ ${ }^{5}$ Faculty of Agriculture, Kyushu University. 744 Motooka Nishi-ku Fukuoka, 8190395, Japan \\ ${ }^{6}$ Faculty of Agriculture, Kyoto University. Kitashirakawa Oiwakecho, Sakyo Ward, Kyoto, 6068224, Japan \\ ${ }^{7}$ Research Center for Medicine and Cosmetic from Tropical Rainforest Resources. J1. Penajam, Kampus Gunung Kelua, Samarinda 75123, East \\ Kalimantan, Indonesia \\ ${ }^{8}$ Division of Exploration and Synthesis of Bioactive Compounds, Research Center for Bio-Molecule Engineering, Universitas Airlangga. J1. Airlangga, \\ Surabaya 60115, East Jawa, Indonesia \\ ${ }^{9}$ Kyushu University Institute for Asian and Oceanian Studies. 744 Motooka Nishi-ku Fukuoka, 8190395, Japan
}

Manuscript received: 25 May 2020. Revision accepted: 14 September 2020.

\begin{abstract}
Syafrizal, Ramadhan R, Kusuma IW, Egra S, Shimizu K, Kanzaki M, Arung ET. 2020. Diversity and honey properties of stingless bees from meliponiculture in East and North Kalimantan, Indonesia. Biodiversitas 21: 4623-4630. Kalimantan Island in Indonesia is covered by tropical rain forests that are rich in biodiversity. Species, include a stingless bee (Trigona spp.). Recently, stingless bee beekeeping (Meliponiculture) in this region has become popular because the honey has a unique taste, a mix of sweet, sour, and bitter which is highly valued. The objective of this study was to determine the diversity of stingless bee species, the number of colonies, type of hive, and honey properties such as taste, acidity, color, phytochemicals, and radical scavenging activity or antioxidant in meliponiculture in selected areas of Eastern and Northern Kalimantan, Indonesia. The area studied included Samarinda, Balikpapan, Penajam, Bontang, Sangatta, and Tarakan. The study conducted by visiting the farmers, collecting the stingless bees species and bee products (honey, propolis, and bee pollen), $\mathrm{pH}$, color and taste determination, phytochemical screening, and DPPH assay. In this study, we found 12 species, with Heterotrigona itama and Tetragonula laeviceps being the main ones cultivated by people in all research areas, except Balikpapan. We counted 111 colonies of $T$. laeviceps and 99 of $H$. itama in the meliponiculture. There were three types of hive used by farmers in meliponiculture. Most of the honey tasted sweet and sour with acidity or $\mathrm{pH}$ ranging from 3-4, and color from dark brown to light yellow. The phytochemicals contained tannin, alkaloid, flavonoid, triterpenoid, carotenoid, coumarin, saponin, and carbohydrate. The Tetragonula sarawakensis honey was the most potent in term radical scavengers. Our findings showed that stingless bee honey contains antioxidants with phytochemicals that are very useful for human health.
\end{abstract}

Keywords: Diverse, Heterotrigona itama, meliponiculture, Tetragonula laeviceps

\section{INTRODUCTION}

Stingless bees are eusocial organisms that dwell in tropical regions. They can be found in South and Central America, Africa, Southwest Asia and Australia. At least 600 species of stingless bees have been identified worldwide and classified into about 60 genera. These bees belong to the family Hymenoptera and subfamily Meliponinae, and they are of high ecological importance (Avila et al. 2018; Basari et al. 2018). Stingless bees gather up and chemically modify floral nectars from the rich plant life in surrounding environments, with specific organic material, such as salivary and enzymes from their cephalic glands (Avila et al. 2019). The stingless bee honey is left to mature inside hives, resulting in unique honey with unusual sour and sweet taste and medicinal functions (Chuttong et al. 2016; Jalil et al. 2017).

Stingless bee beekeeping is called meliponiculture.
Human use of stingless bees is an ancient undertaking, although not overly well archived in the archaeological record. The oldest evidence of the utilization of stingless bees is from the pre-Columbian Mayans in Meso-America (Chuttong et al. 2014). Meliponiculture has been managed at varying levels by traditional societies throughout the equatorial range of stingless bees. It is currently, it is most widely practiced in Neotropical realms, including in Asia, with many species (Chuttong et al. 2016).

In Indonesia, meliponiculture began trending in 2010 when a farmer in Radda village, North Luwu District, South Sulawesi Province, Indonesia, sold 50 liters of honey and $30 \mathrm{~kg}$ of propolis. By 2014, a farmer in Rumpin, a village in the Bogor District, West Java Province, Indonesia, had 200 colonies in wood logs. Meliponiculture has increased as products such as honey, bee pollen, and propolis have gained economic value (Fadhilah and Rizkika 2015). However, to the best of our knowledge, no 
studies have examined the diversity, number of the colony, type of hive, and honey properties of Indonesia's meliponiculture, especially in East and North Kalimantan. Therefore, in this study, we explore diverse species of stingless bees, bee size, number of the colony, type of hive in the meliponiculture of East and North Kalimantan, Indonesia and the properties of the honey.

\section{MATERIALS AND METHODS}

\section{Study area}

The study area included parts of Samarinda (SMD), Balikpapan (BPN), Penajam Pasir Utara (PPU), Bontang (BTG) and Sangatta (SGT) in East Kalimantan and Tarakan (TRK) in North Kalimantan, Indonesia (Figure 1).

\section{Stingless bees identification and collection of their products}

In this study, stingless bees and their products (honey, propolis, and bee pollen) were collected from the survey locations in 2018 and 2019, and bees specimens were kept at Biology Laboratory, Faculty of Mathematics and Science, Mulawarman University, Samarinda, East Kalimantan. The specimens were identified by Dr. Syafrizal (Biology Department, Faculty of Mathematics and Natural Sciences, Mulawarman University, Samarinda, Indonesia) using the taxonomic key of Schwarz (1939), Rasmussen (2008) and Syafrizal, 2014 (unpublished data). All specimens were deposited in this laboratory. The honey, propolis, and bee pollen from studied locations were taken per its species in the selected colony. These samples were kept and treated in the Laboratory of Forest Product Chemistry, Forestry Faculty, Mulawarman University.
Some honey and bee pollens were not available at the time, therefore we can not analyze it. Here, we analyzed the properties of available honey, but propolis and bee pollen remain in the laboratory refrigerator analysis at a future time.

\section{Adicity (pH) determination}

All collected honey was directly determined for the acidity in the field. Litmus paper (Universal Test Paper $\mathrm{pH}$ $0-14$, Suncare) was used to determine the acidity of honey according to the manufacturer's instruction.

\section{Color and taste determination}

The color was determined by simple qualitative visual assessment. Similarly, taste assessment was directly in the field by Dr. Syafrizal.

\section{Honey preparation for analysis}

All collected honey was stored in a refrigerator $\left(4^{\circ} \mathrm{C}\right)$. The honey was put in room temperature for 30-60 minutes prior to DPPH (1,1-diphenyl-2-picrylhydrazyl) and phytochemical analysis. In this analysis, the honey was not extracted with any solvents and then was directly mixed to working solution in DPPH or phytochemical analysis.

\section{Phytochemical screening}

Phytochemicals test were used to screen for the presence of tannins, alkaloids, flavonoids, alkaloids, terpenoids, steroids, carotenoids, coumarin, and saponins. Carbohydrates also were tested qualitatively. The screening tests for these major phytochemicals and carbohydrates were carried out using standard qualitative procedures described by Oscar et al. (2020) and Viji et al. (2013), with some modifications as follows:
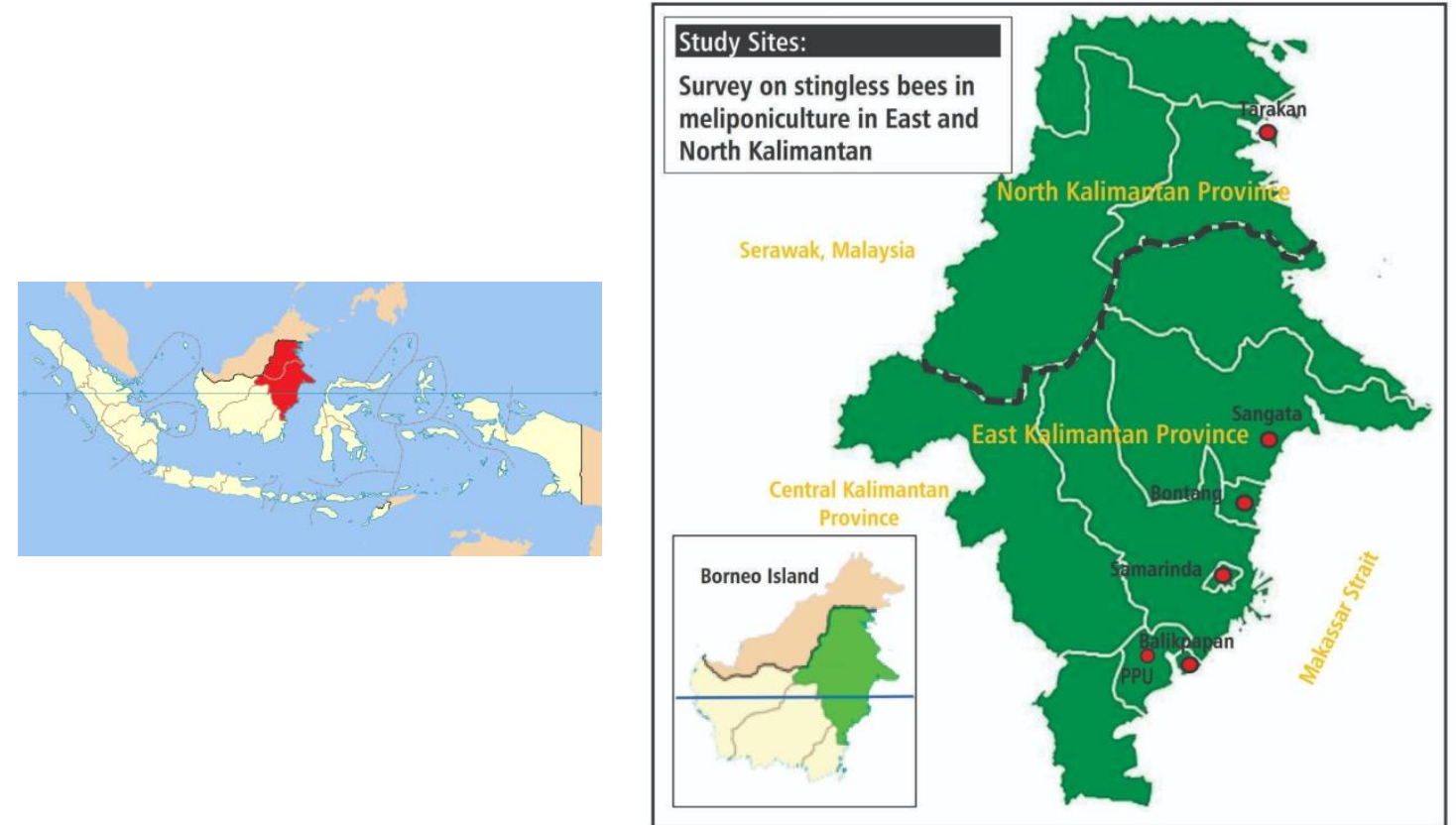

Figure 1. Location of survey in East and North Kalimantan, Indonesia 


\section{Detection of tannins}

The honey $(1 \mathrm{~mL})$ was mixed with three drops of freshly prepared $1 \%$ lead acetate. The formation of yellow precipitates was considered a positive test for tannins presence (Oscar et al. 2020).

\section{Detection of alkaloids}

Five $\mathrm{mL}$ of honey were mixed carefully with $2 \mathrm{~mL}$ of $\mathrm{HCl}$ in the test tube and $1 \mathrm{~mL}$ Dragendorff reagent was added. The formation of a yellow-colored precipitate indicated the presence of alkaloids in the honey (Oscar et al. 2020).

\section{Detection of flavonoids}

The honey $(1 \mathrm{~mL})$ was treated with 5 drops of $1 \%$ sodium hydroxide solution. The formation of intense yellow color, followed a colorless solution formed on the addition of a dilute acid ( $\mathrm{HCl} 1 \%)$, indicated of the presence of flavonoids in the honey (Viji et al. 2013).

\section{Detection of triterpenoid and steroid}

A mixture of ten drops of acetic anhydride and two drops of concentrate sulfuric acid was treated with $1 \mathrm{~mL}$ of honey diluted in acetone. The resultant mixture was shaken vigorously. Red or purple color change indicated the presence of triterpenoid, while a blue-green color signified that steroids were present (Oscar et al. 2020).

\section{Detection of carotenoids}

One $\mathrm{mL}$ of honey was diluted with $5 \mathrm{~mL}$ chloroform in a test tube, shaken vigorously, and four drops of $85 \%$ sulfuric acid were added. The blue color on the surface of mixtures indicated carotenoids' presence (Viji et al. 2013).

\section{Detection of coumarins}

One $1 \mathrm{~mL}$ of honey was treated with four drops of sodium hydroxide and alcohol. The solution turnings yellow indicated the presence of coumarins (Viji et al. 2013).

\section{Detection of saponins}

The honey $(60 \mathrm{mg}$ ) was mixed with $2 \mathrm{~mL}$ of acetone, and $3 \mathrm{~mL}$ hot water was added. The solution was cooled and then shaken vigorously for 10 seconds. The formation of bubbles or persistent foam $1-10 \mathrm{~cm}$ high for 10 minutes following the addition of one drop $\mathrm{HCl} 2 \mathrm{~N}$, and continuing froth, indicated saponins' presence of in the honey (Viji et al. 2013).

\section{Detection of carbohydrates}

One $\mathrm{mL}$ of honey was dissolved in $1 \mathrm{ml}$ of acetone in a test tube, and then treated with one drop of Molisch's reagent. The resultant mixture was shaken strongly and treated with $1 \mathrm{~mL}$ of sulfuric acid. Purple rings between two layers of mixtures indicated the presence of carbohydrates (Viji et al. 2013).

\section{Radical scavenging (DPPH) assay}

The DPPH assay was performed as described in Arung et al. (2015). Briefly, $500 \mu \mathrm{L}$ of $60 \mu \mathrm{M} \mathrm{DPPH}$ and $467 \mu \mathrm{L}$ of ethanol were used as working solutions. The positive control in this assay was Vitamin C at $100 \mathrm{mg} / \mathrm{ml}$. The honey concentration was $100 \%$ (pure honey or without mixing with any solvents) and directly mixed into the working solution.

\section{RESULTS AND DISCUSSION}

\section{Species, colony, and size}

Meliponiculture in East and North Kalimantan has recently developed in Samarinda, Balikpapan, Penajam Paser Utara, Bontang, Sangatta, and Tarakan. Based on our study, about twelve stingless bee species were identified, and 325 colonies were identified and documented in the study areas (Table 1 and Table 2). The twelve species were Geniotrigona thoracica, Heterotrigona bakeri, Heterotrigona itama, Lepidotrigona terminata, Homotrigona fimbriata, Tetragonula biroii, Tetragonula fuscobalteata, Tetragonula iridipennis, Tetragonula laeviceps, Tetragonula reepeni, Tetragonula sarawakensis, and Tetragonula testaceitarsis. T. laeviceps was strongly preferred by beekeepers and this species constituted $31.49 \%$ of total colony research results, followed by $H$. itama $(24.38 \%$ ) (Table 1). These two species made up about $55.87 \%$ of all colonies of cultivated stingless bees. The colonies of T. laeviceps in Tarakan had been purchased from Jawa Island. Therefore, there was a large number of them (31.49\%). In Thailand, T. laeviceps and T. pagdeni are the most familiar, and readily accept human-made domiciles (Chuttong et al. 2014). The H. itama had been collected from the forest by the farmer, but in Bontang, the farmer bought the colonies from Banjar Baru (South Kalimantan). H. itama was a favorite among farmers because of the quality/quantity of the honey and easy to cultivate. Kelly et al. (2014) reported meliponiculture in Kelantan Malaysia, where Heterotrigona itama and Geniotrigona thoracica were the most popular with farmers and colonies numbered 134 and 18, respectively.

In our study, we found various body sizes of the stingless bee, as shown in Figure 2. The biggest was $H$. fimbriata and the smallest was T. fuscobalteata. Body size had an obvious affect on the honey, propolis, and bee pollen production. Stingless bees vary widely in body size; species range from about the size of big to small honey bee workers. Body size influences the flight distance and foraging activities of stingless bees, with bigger body size enabling longer flight distances and larger regions for good food source (Streinzer et al. 2016).

\section{Type of hive}

Traditional methods of meliponiculture in these areas have several types of hives. We found that farmers kept stingless bee in hollow tree trunks with box of the top, one layer of wooden box, and three-layer wooden box (Figure 3 ). The hollow tree trunks were the initial colony hives with diverse diameters, farmers added wooden boxes on the top. Artificial hives were made of wooden boards, boxshaped pieces covered by plastic or wooden to facilitate the control of harvesting. Kelly et al. (2014) found that 
meliponiculture in Kelantan, Malaysia, used two types of external hive; hollow tree trunk, and artificial wood box. Most of the farmers in the study area preferred hollow tree trunks for larger stingless bees (such as H.itama and $G$. thoracica) and artificial boxes for the smaller bees (such as
T. laeviceps, T. reepeni, T.testaceitarsis, and $T$. fuscobalteata). Chuttong et al. (2014) reported that farmers in Thailand used three types of hives; boxes (for $T$. laeviceps, T. pagdeni, and L. flavibasis), tree trunks ( $L$. doipaensis), and split logs (L. terminata).

Table 1. Stingless bee species and number of colonies in East and North Kalimantan, Indonesia meliponiculture

\begin{tabular}{|c|c|c|c|c|c|c|c|c|}
\hline \multirow{2}{*}{ Species } & \multicolumn{8}{|c|}{ Site area } \\
\hline & SMD & BPN & PPU & BTG & SGT & TRK & Colony (number) & Percentage $(\%)$ \\
\hline Geniotrigona thoracica & 0 & 0 & 0 & 0 & 0 & 4 & 4 & 1.38 \\
\hline Heterotrigona bakeri & 10 & 0 & 0 & 0 & 0 & 4 & 14 & 4.84 \\
\hline Heterotrigona itama & 20 & 0 & 4 & 50 & 10 & 15 & 99 & 24.38 \\
\hline Lepidotrigona terminata & 0 & 0 & 2 & 0 & 2 & 0 & 4 & 1.38 \\
\hline Homotrigona fimbriata & 1 & 0 & 0 & 0 & 0 & 0 & 1 & 0.34 \\
\hline Tetragonula biroi & 0 & 20 & 0 & 0 & 5 & 0 & 20 & 8.65 \\
\hline Tetragonula fuscobalteata & 4 & 0 & 0 & 10 & 0 & 10 & 24 & 13.14 \\
\hline Tetragonula iridipennis & 5 & 0 & 0 & 0 & 0 & 0 & 5 & 1.73 \\
\hline Tetragonula laeviceps & 20 & 0 & 6 & 20 & 5 & 60 & 111 & 31.49 \\
\hline Tetragonula reepeni & 6 & 0 & 0 & 0 & 0 & 0 & 6 & 2.07 \\
\hline Tetragonula sarawakensis & 6 & 0 & 0 & 0 & 0 & 5 & 11 & 3.80 \\
\hline Tetragonula testaceitarsis & 10 & 0 & 2 & 0 & 5 & 4 & 21 & 7.95 \\
\hline Total & 82 & 20 & 14 & 80 & 27 & 102 & 325 & \\
\hline
\end{tabular}

Note: Samarinda (SMD, Balikpapan (BPN), Penajam Pasir Utara (PPU), Bontang (BTG) and Sangatta (SGT) in East Kalimantan and Tarakan (TRK)

Table 2. Acidity $(\mathrm{pH})$ value of stingless bee honey

\begin{tabular}{|c|c|c|c|c|c|c|}
\hline \multirow{2}{*}{ Species } & \multicolumn{6}{|c|}{ pH * } \\
\hline & SMD & BPN & PPU & BTG & SGT & TRK \\
\hline Geniotrigona thoracica & $\mathrm{ND}$ & ND & ND & ND & ND & ND \\
\hline Heterotrigona bakeri & 3 & ND & ND & ND & ND & ND \\
\hline Heterotrigona itama & 4 & ND & ND & ND & ND & 3 \\
\hline Lepidotrigona terminata & ND & ND & 3 & ND & ND & ND \\
\hline Homotrigona fimbriata & 3 & ND & ND & ND & ND & ND \\
\hline Tetragonula biroi & ND & 3 & ND & ND & ND & ND \\
\hline Tetragonula fuscobalteata & 3 & ND & ND & ND & ND & 3 \\
\hline Tetragonula iridipennis & 3 & ND & ND & ND & ND & ND \\
\hline Tetragonula laeviceps & 4 & ND & ND & ND & ND & ND \\
\hline Tetragonula reepeni & 4 & ND & ND & ND & ND & ND \\
\hline Tetragonula sarawakensis & 4 & ND & ND & ND & ND & ND \\
\hline Tetragonula testaceitarsis & 4 & ND & ND & ND & ND & 4 \\
\hline
\end{tabular}

Note: * Determined using Litmus paper. ND: not determined (honey was not available):

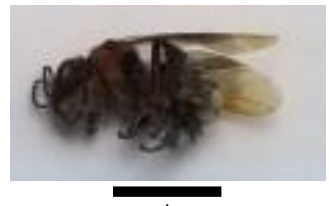

$\mathbf{A}$
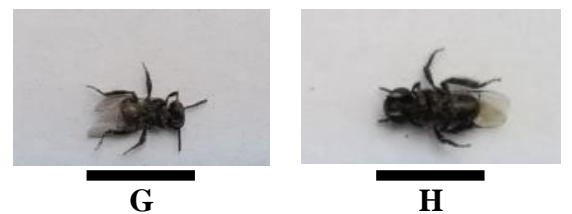

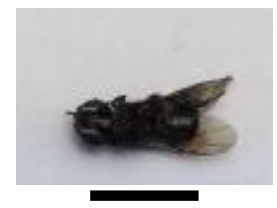

$\mathbf{C}$

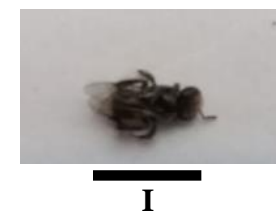

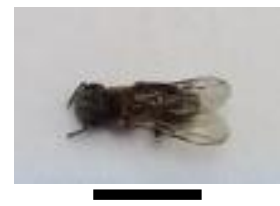

D

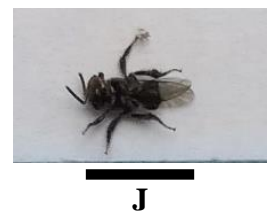

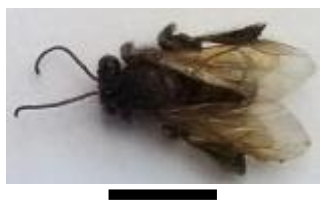

$\mathbf{E}$
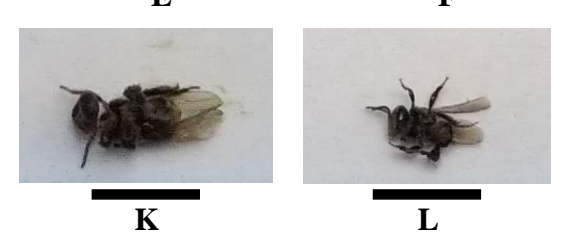

Figure 2. Species and sizes of stingless bee in East and North Kalimantan (Indonesia) meliponiculture. A. Geniotrigona thoracica, B. Heterotrigona bakeri, C. Heterotrigona itama, D. Lepidotrigona terminata, E. Homotrigona fimbriata, F. Tetragonula biroi, G. Tetragonula fuscobalteata, H. Tetragonula iridipennis, I. Tetragonula laeviceps, J. Tetragonula reepeni, K. Tetragonula sarawakensis, L. Tetragonula testaceitarsis. Bar $=0.5 \mathrm{~cm}$ 


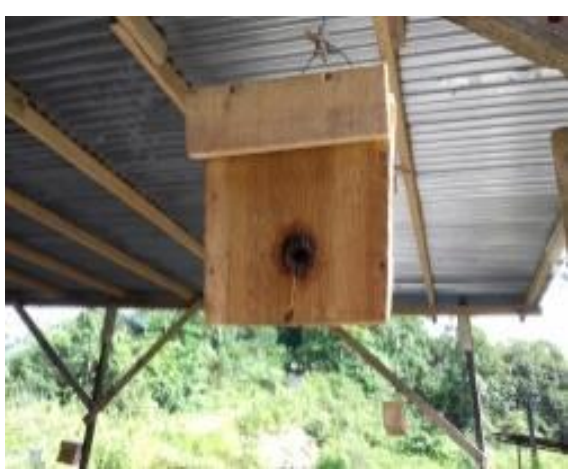

A

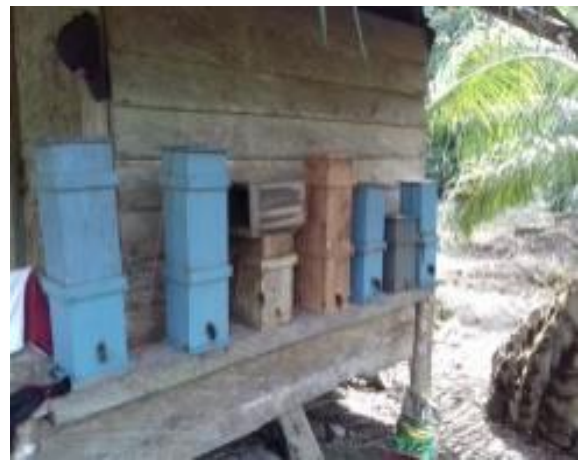

B

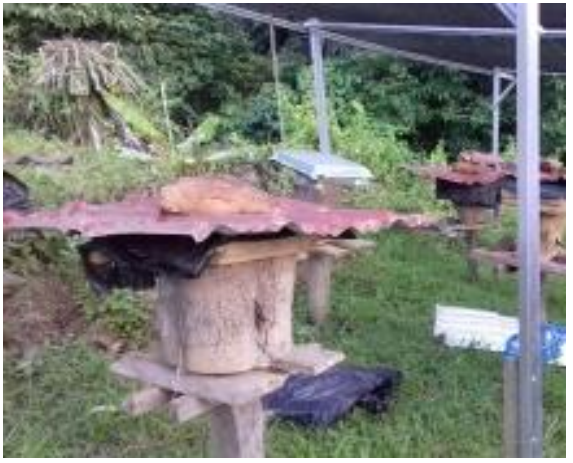

C

Figure 3. Types of hive: A. One layer wooden box; B. Two-three layer wooden box; C. Trunk with box on the top

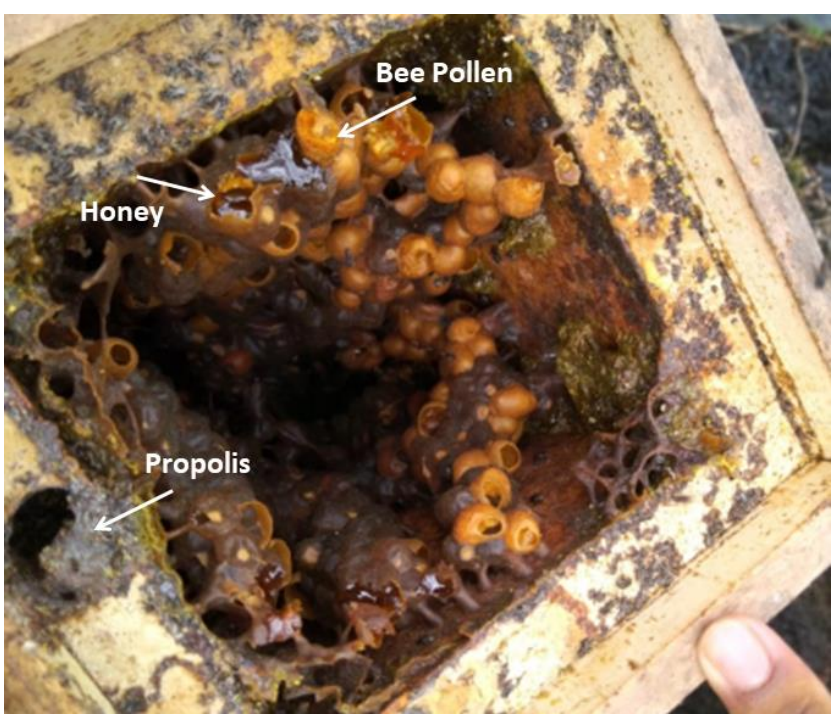

Figure 4. Stingless bee product's (honey, bee pollen, and propolis)

\section{Honey properties}

Products from stingless bees include honey, pollen, wax, and propolis/cerumen. Of these, honey is the most valuable and was related to health functions by ancient peoples. It may have been used in the culture and as an income source for many generations (Jalil et al. 2017). Currently, the honey produced by stingless bees and Apis bees are the two types and marketed worldwide (Avila et al. 2018). In this study, we collected stingless bee honey (Figure 4) directedly from the farmers. Below, we report some of the properties of stingless bee honey that we determined in this study.

\section{Acidity $(\mathrm{pH})$ and taste}

The stingless bee honey is different than honey Apis mellifera (honeybee). The main differences are higher water content, lower diastase activity, and a different sugar spectrum (Rodríguez-Malaver et al. 2009). The stingless bee honey has a unique flavor, which includes a sour taste. The sourness led us to determine the acidity value $(\mathrm{pH})$ by Litmus paper, as shown in Table 2. The $\mathrm{pH}$ of the honey in 11 species (12 samples) was 3 and 4 . We did not have a sample of $G$. thoracica, and therefore no data were available. Avila et al. (2018) reported that the acidity of 88 species of stingless bee honey ranged from 3-5. Most have acidity between 3 and 4, and only Melipona mondury was 5. Avila et al. (2018) reported that honey bee (Apis mellifera) acidity was in the 3-4 range.

The flavor of the stingless bee honey is unique because of its sour taste. In this study, Table 3 shows that the taste of each honey has two distinct flavors, sweet and sour. Avila et al. (2019) reported that when this stingless bee honey is stored and left to mature inside the pot, it results in an unusual level of sourness, sweetness, and health value. In addition, we found that the degree of sourness increased with the body size of the stingless bee, as pointed out in honey taste of $H$. fimbriata $>H$. bakeri, H.itama>T.testaceitarsis, $T$. laeviceps, $T$. reepeni, T.iridipennis, T. biroi, T. terminata, T. sarawakensis, and T. fuscobalteata. Many factors can affect taste or flavor, Cianciosi et al. (2018) found that the differences of composition, taste, and color in honey were caused by flower source, geographical, climate, species, processing, and storage.

\section{Color}

Color is a physical property that consumers can easily be recognized. Stingless bees honey is a valuable product from stingless bees different from Apis bees in terms of taste, color, and viscosity (Rao et al. 2016). In Table 3, we described the result of qualitative color and taste from 14 samples of stingless bees honey. We found the color of stingless bee honey ranged from the light yellow - dark brown. We also found that honey of the same species could differ in color based on location. T. testaceitarsis was light brown in Samarinda but light yellow in Tarakan; H. itama was yellow in Samarinda but dark brown in Tarakan; $T$. fuscobalteata was light yellow in Samarinda and brown inTarakan. Avila et al. (2018) reported the color of stingless bee honey quantitatively using the Pfund scale; they found it ranged from 50.0-70.0 mm Pfund, or light amber (yellow-orange). Rao et al. (2016) reported that the color of stingless bee honey was generally dark amber. Several factors can affect the color of the honey, such as ash content (more ash made the color amber-brown), heat, light exposure, duration of storage, enzymatic reaction, and presence of various compounds. 
Table 3. Phytochemicals, color, and taste of stingless bee honey

\begin{tabular}{|c|c|c|c|c|c|c|c|c|c|c|c|}
\hline \multirow{2}{*}{ Honey } & \multicolumn{9}{|c|}{ Phytochemical } & \multirow{2}{*}{ Color } & \multirow{2}{*}{ Taste } \\
\hline & Tan & Alk & Fla & Tri & Ste & Car & Cou & Sap & Cbo & & \\
\hline H. fimbriata (SMD) & + & + & + & + & - & - & + & + & + & Brown & Very Sour and a bit sweet \\
\hline T. testaceitarsis (SMD) & + & - & + & + & - & - & + & - & + & Light brown & Sweet and a bit sour \\
\hline T. laeviceps (SMD) & + & + & + & + & - & - & + & - & + & Brown & Sweet and a bit sour \\
\hline T. reepeni (SMD) & + & + & + & + & - & - & + & - & + & Light yellow & Sweet and a bit sour \\
\hline H. bakeri (SMD) & + & + & + & + & - & - & + & - & + & Dark brown & Sour and a bit sweet \\
\hline H. itama (SMD) & + & + & + & - & - & - & + & + & + & Yellow & Sour and a bit sweet \\
\hline T. iridipennis (SMD) & + & - & + & + & - & - & + & + & + & Dark yellow & Sweet and a bit sour \\
\hline T. fuscobalteata (SMD) & + & + & + & + & - & - & + & + & + & Light yellow & Sweet and a bit sour \\
\hline T. sarawakensis (SMD) & + & + & + & - & - & - & + & - & + & Light yellow & Sweet and a bit sour \\
\hline T. fuscobalteata (TRK) & + & + & + & + & - & - & + & + & + & Brown & Sweet and a bit sour \\
\hline H. itama (TRK) & + & + & + & + & - & - & + & - & + & Dark brown & Sweet and a bit sour \\
\hline T. testaceitarsis (TRK) & + & + & + & + & - & - & + & - & + & Light yellow & Sweet and a bit sour \\
\hline T. biroi $(\mathrm{BPN})$ & + & - & + & + & - & - & + & - & + & Brown & Sweet and a bit sour \\
\hline L. terminata (PPU) & + & - & + & + & - & - & + & - & + & Dark yellow & Sweet and a bit sour \\
\hline
\end{tabular}

Note: SMD: Samarinda; TRK: Tarakan; Tan: Tannin; Alk: Alkaloid; Fla: Flavonoid; Tri: Triterpenoid; Ste: Steroid; Car: Carotenoid; Cbo: Carbohydrate; Cou: Coumarin; Sap: Saponin

\section{Phytochemical screening}

Phytochemical screening of stingless bee honey revealed a wide range of phytochemicals (Table 3). Qualitative phytochemical screening carried out on the honey from study areas of East and North Kalimantan showed the presence of compounds groups such as: tannins, alkaloids, flavonoids, triterpenoids, steroids, carotenoids, coumarins, and saponins as the secondary metabolite, and carbohydrates as the primary metabolite. To our knowledge, no previous studies have conducted phytochemical screening of honey from stingless bees from East and North Kalimantan. As shown in Table 3, all of the honey contained tannin, flavonoids, coumarin, and carbohydrates. In contrast, not all contained steroids and carotenoids. Moreover, honey from H. itama (Samarinda) and T. sarawakensis did not have triterpenoid content. That from T. testaceitarsis, T. iridipennis, T. biroi, and $L$. terminata did not contain alkaloids, while that from $T$. testaceitarsis, T. laeviceps, T. reepeni, H. bakeri, $T$. sarawakensis, H. itama (Tarakan), T. testaceitarsis (Tarakan), T. biroi, and L. terminata did not have saponin.

Cianciosi et al. (2018) found that honey has 180 types of compounds, including water, sugars, free amino acids, proteins, enzymes, minerals, vitamins, and some phytochemicals. Several scientists have reported that the honey of the stingless bee contains phytochemicals. Avila et al. (2018) found that the honey of 10 stingless bees (Melipona crinita, Melipona eburnea, Melipona grandis, Melipona illota, Nannotrigona melanocera, Partamona epiphytophila, Ptilotrigona lurida, Scaptotrigona postica, Scaura latitarsis, and Tetragonisca angustula) from Peru had phenolics and flavonoids; and T. iridipennis in India also contained phenolics and flavonoids (Krishnasree and Ukkuru 2015). Bakar et al. (2017) reported the honey of two stingless bees (H. itama and G. thoracica) had phenolics, flavonoids, and carbohydrates. Avila et al.
(2018) summarized the honey content of 88 stingless bees; some included phenolics, flavonoids, carotenoids, carbohydrates, and tannin. In a later study, the same researchers (Avila et al. 2019) reported the honey of four stingless bees in Brazil (Melipona bicolor, Melipona quadrifasciata, Melipona marginata, and Scaptotrigona bipunctata) contained phenolics, flavonoids, and tannin. Biluca et al. (2020) reported on the honey of six stingless bees (Scaptotrigona bipunctata, Melipona marginata, Tetragonisca angustula, Trigona hypogea, Melipona quadrifasciata, and Tetragona clavipes), finding phenolics, flavonoids, coumarin, and terpenoid. The phytochemical results of these reports were quantitative. Like our results, none of these reports found steroid compounds. Our results did not detect carotenoid. It might be that this compound appears in very small amounts, as reported by Avila et al. (2018). They found carotenoid in the honey of Scaptotrigona mexicana was $0.6-6.5 \mathrm{mg} / \mathrm{kg}$ compared to other compounds. On the other hand, we detected a saponin compound in stingless bee honey not found in the honey of other stingless bees.

\section{Antioxidant activity}

The phytochemical screening results of the stingless bee honey listed in Table 3 were used to evaluate antioxidant activity. This property is associated with the capability of secondary metabolites to neutralize the effects of free radicals and oxygen reactive species in the body (Oscar et al. 2020). Based on the tests of stingless bee honey (Figure 5), the honey of $T$. sarawakensis (SMD) showed the lowest percentage of radical scavenging activity (sample vs. control (\%)) of the honey examined. The lowest \% scavenging activity values of the honey of $T$. reepeni (SMD) reflect a huge amount of secondary metabolites, especially phenolic compounds. 


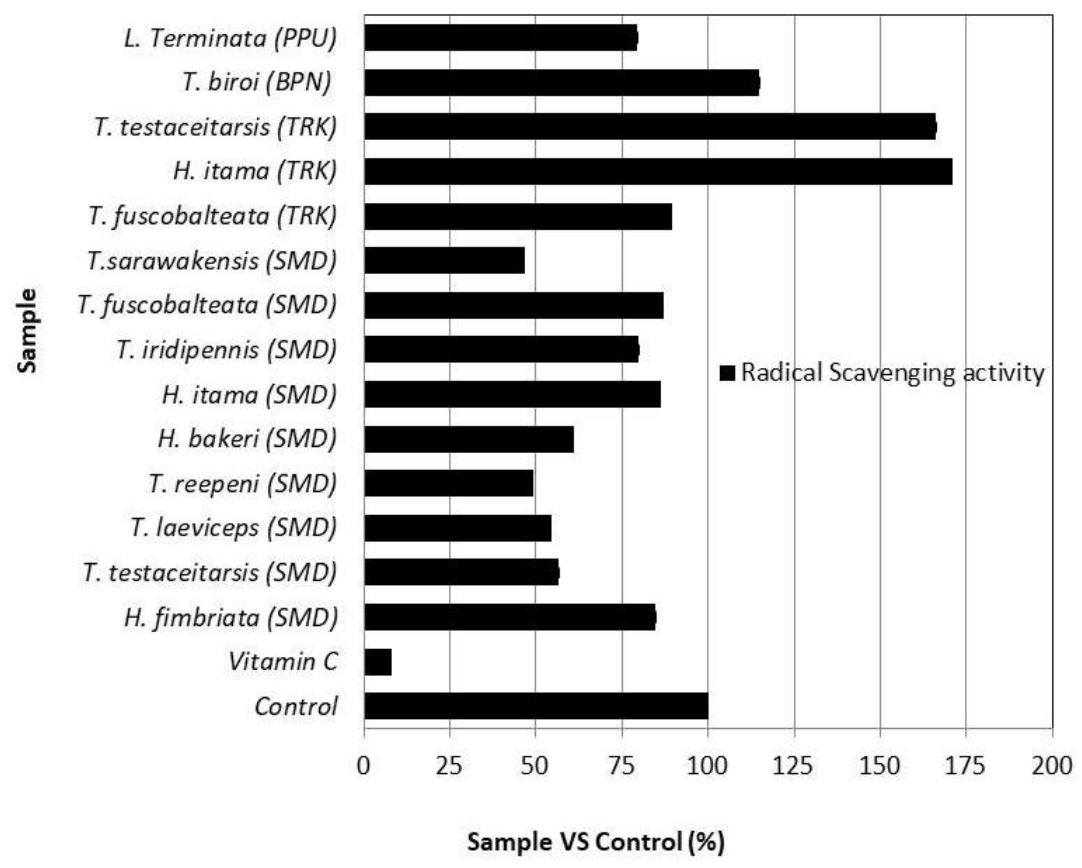

Figure 5. Radical scavenging activity of Stingless bee honey. SMD: Samarinda; BPN: Balikpapan; PPU: Penajam Paser Utara; TRK: Tarakan. Vitamin C was $100 \mathrm{mg} / \mathrm{ml}$ and honey was pure (without mixing any solvents)

The honey antioxidant activity of $T$. reepeni (SMD) is thought to be due to the presence of flavonoids, tannins, and coumarin. Phenol and flavonoid compounds have a linear contribution to antioxidant activity, so there is a positive correlation between the presence of tannins, flavonoids, and coumarin and antioxidant activity (Ghasemzadeh and Ghasemzadeh 2011). Further research is needed to isolate the active compounds of stingless bees honey that is natural antioxidants. The phenolic compounds in 10 species of stingless bee honey (Scaptotrigona bipunctata, Melipona bicolor, Melipona quadrifasciata, Tetragonisca angustula, Melipona mondury, Melipona rufiventris mondury, Melipona marginata, and Trigona fuscipennis, Melipona scutellaris, Tetragona clavipes) showed antioxidant activity (Biluca et al. 2016), as did phenolics such as salicylic, protocatechuic, $p$-coumaric, caffeic, ferulic, 4-amino benzoic, chlorogenic, rosmarinic, vanillic, and mandelic detected in the honey of six stingless bees from Brazil (Biluca et al. 2020). The stingless bee honey of $T$. iridipennis from India was reported to contain phenolics and flavonoids with antioxidant activity (Krishnasree and Ukkuru 2015). In addition, the honey of stingless bee Scaptotrigona mexicana from Mexico contained polyphenols (flavonoid and phenolic) and carotenoids shown to have antioxidant activities (Avila et al. 2018).

In conclusion, we found that meliponiculture in East and North Kalimantan was developing in six cities, five in East Kalimantan and one in North Kalimantan. The species of stingless bees were varied in each meliponiculture area (types of hive and bees size), as was the taste (sweet and sour), color (yellow-brown), acidity (3-4 pH), phytochemical content (tannin, alkaloid, flavonoid, triterpenoid, coumarin, saponin, and carbohydrate), and antioxidant capacity ( $T$. sarawakensis and $T$. reepeni) of the honey. These properties showed the uniqueness of stingless bees honey compared to Apis bee honey. Further research is needed to determine other health functions of stingless bees honey.

\section{ACKNOWLEDGEMENTS}

A part of this work was funded by the Japan-ASEAN Science, Technology and Innovation Platform (JST SICORP Japan (Grant no. JPMJSC15H1 for Enos Tangke Arung), the Ministry of Research, Technology and Higher Education, Republic of Indonesia in the scheme of the Excellence Basic Research (Grant no. 080/UN17.41/KL/2018 for Syafrizal); Basic Research 2019 (Grant no. 198/UN17.41/KL/2019 for Enos Tangke Arung), Word Class Research (Grant no. 204/UN17.41/KL/2019 for Enos Tangke Arung), and Kyushu University Institute for Asian and Oceanian Studies (Q-AOS) for Kuniyoshi Shimizu. We would like to thank Rendri Arista Avimaro (Samarinda), Syarif Ismail (Penajam), Lalu Fauzul Idhi (Balikpapan), Muhsin Lappema (Sangatta), Rendra Chaniago (Bontang), and Jaini (Tarakan) for their hospitality and kindness in providing samples (honey, cerumen/propolis, and bee pollen) for this research. The authors have no conflicts of interest to declare. 


\section{REFERENCES}

Arung ET, Suwinarti W, Hendra M, Supomo, Kusuma IW, Puteri DCN, Eroglu HA, Kim Y, Shimizu K, Ishikawa H. 2015. Determination of antioxidant and anti-melanogenesis activities of Durio kutejensis [Bombacaceae (Hassk.) Becc] (Indonesian Lai) fruit extract. Trop J Pharmaceut Res 14 (1): 41-46.

Avila S, Beux MR, Ribani RH, Zambiazi RC. 2018. Stingless bee honey: Quality parameters, bioactive compounds, health promotion properties and modification detection strategies. Trends Food Sci Technol 81: 37-50. DOI: 10.1016/j.tifs.2018.09.002

Avila S, Hornung PS, Teixeira GL, Malunga LN, Apea-Bah FB, Beux MR, Beta T, Ribani RH. 2019. Bioactive compounds and biological properties of Brazilian stingless bee honey have a strong relationship with the pollen floral origin. Food Res Intl 123: 1-10. DOI: 10.1016/j.foodres.2019.01.068

Bakar MFA, Sanusi SB, Bakar FIA, Cong OI, Mian Z. 2017. Physicochemical and antioxidant potential of raw unprocessed honey from Malaysian Stingless Bee. Pak J Nur 16 (11): 888-894.

Basari N, Ramli SN, Khairi NASM. 2018. Food reward and distance influence the foraging pattern of Stingless Bee, Heterotrigona itama. Insects 9 (4): 138. DOI: 10.3390/insects9040138.

Biluca FC, Braghini F, Gonzaga LV, Costa ACO, Fett R. 2016 Physicochemical profiles, minerals and bioactive compounds of stingless bee honey (Meliponinae). J Food Compost Anal 50: 66-69. DOI: 10.1016/j.jfca.2016.05.007.

Biluca FC, da Silva B, Caon T, Talita E, Mohr B, Vieira GN, Gonzaga LV, Vitali L, Micke G, Fett R, Dalmarco EM, Costa ACO. 2020 Investigation of phenolic compounds, antioxidant and antiinflammatory activities in stingless bee honey (Meliponinae). Food Res Intl 129: 108756. DOI: 10.1016/j.foodres.2019.108756.

Chuttong B, Chanbang Y, Burgett M. 2014. Meliponiculture: Stingless bee beekeeping in Thailand. Bee World 91 (2): 41-45. DOI: 10.1080/0005772X.2014.11417595.

Chuttong B, Chanbang Y, Sringarm K, Burgett M. 2016. Physicochemical profiles of stingless bee (Apidae: Meliponini) honey from South East Asia (Thailand). Food Chem 192: 149-155. DOI: 10.1016/j.foodchem.2015.06.089.

Cianciosi D, Forbes-Hernández TY, Afrin S, Gasparrini M, ReboredoRodriguez P, Manna PP, Zhang J, Lamas LB, Flórez SM, Toyos PA,
Quiles JL, Giampieri F, Battino M. 2018. Phenolic compounds in honey and their associated health benefits: A review. Molecules 23: 2309-2322. DOI: 10.3390/molecules23092322

Fadhilah R, Rizkika K. 2015. Profit of stingless bee. PT.Trubus Swadaya, Jakarta. www.trubus-online.co.id. [Indonesian]

Ghasemzadeh A, Ghasemzadeh N. 2011. Flavonoids and phenolic acids: Role and biochemical activity in plants and human. J Med Plan Res 5 (31): 6697-6703.

Jalil MAA, Kasmuri AR, Hadi H. 2017. Stingless bee honey, the natural wound healer: A review. Skin Pharmacol Physiol 30 (2): 66-75. DOI: $10.1159 / 000458416$

Kelly N, Farisya MSN, Kumara TK, Marcela P. 2014. Species diversity and external nest characteristic of stingless bees in meliponiculture. Pertanika J Trop Agricul Sci 37 (2): 293-298.

Krishnasree V, Ukkuru PM. 2015. Phytochemical screening and antioxidant activity of different bee honey. J Med Herbs Ethnomed 1 (1): 38-44.

Oscar S, Antonio C, Marina G, Elsa R, Gabriel V. 2020. Phytochemical screening, antioxidant activity, and in vitro biological evaluation of leaf extracts of Hyptis suaveolens (L.) Poit. South Afr J Biol 128: 6266. DOI: 10.1016/j.sajb.2019.10.016

Rao PV, Krishnana KT, Salleh N, Gan SH. 2016. Biological and therapeutic effects of honey produced by honey bees and stingless bees: A comparative review. Rev Bras Farmacogn 26 (5): 657-664. DOI: 10.1016/j.bjp.2016.01.012

Rasmussen C. 2008. Catalog of the Indo-Malayan/Australasian stingless bees (Hymenoptera: Apidae: Meliponini). Zootaxa 1935 (1935): 1-80. DOI: 10.11646/zootaxa.1935.1.1

Rodríguez-Malavera AJ, Rasmussen C, Gutiérrez MG, Gild F, Nieves B, Vit P. 2009. Properties of honey from ten species of Peruvian stingless bees. Nat Prod Commu 4 (9): 1221-1226.

Schwarz HF. 1939. The Indo-Malayan species of Trigona. Bull Am Mus Nat His 76: 83-141.

Streinzer M, Huber W, Spaethe J. 2016. Body size limits dim-light foraging activity in stingless bees (Apidae: Meliponini). J Comp Physiol A 202 (9): 643-655. DOI: 10.1007/s00359-016-1118-8

Viji GS, Vasanthe B, Suresh K. 2013. Screening and antibacterial activity analysis of some important medicinal plants. Intl J Innov Appl Stud 2 (2): $146-152$ 